\title{
EFFect of Different Processing ON THE ROUGHNESS OF OAK AND BEECH WOOD
}

\author{
SElver Smajic, Juraj Jovanovic \& RuZica BelJo LuCIC
}

Abstract: The surface of wood elements is the result of the complex interaction of anatomical, physical and mechanical properties of wood, and the types and parameters of the machining process. This paper presents the research on the effect of two different machining methods on the surface roughness of oak (Quercus robur L.) and beech (Fagus sylvatica L.) wood samples. The first machining method was planing (peripheral milling), with four blades and four feed rates. The cutting depth was 1.00 mm, blade rake angle $\gamma=15^{\circ}$, cutting edge diameter $\Phi=125 \mathrm{~mm}$ and rotational frequency of the tool was $8000 \mathrm{~min}^{-1}$. The second processing machine was the automatic milling and widebelt sanding machine, with a head of the milling tool and sanding roller with $P 80$ granulation. The cutting edge diameter of the milling tool was $\Phi=250 \mathrm{~mm}$, rake angle $\gamma=15^{\circ}$ and feed rate $10 \mathrm{~m} \cdot \mathrm{min}^{-1}$. The depth of milling and sanding was $1.50 \mathrm{~mm}$. The electrical-mechanical profiler Mitutoyo SJ-500 was used for measuring surface roughness according to ISO 4287:1997, through parameters $R a, R q$, and $R z$. The study results showed different average values of surface roughness parameters for different machining methods for both wood species. The lowest roughness had beech and oak samples planed at a feed rate of $10 \mathrm{~m} \cdot \mathrm{min}^{-1}$. The highest surface roughness had beech and oak wood samples which were planed at a feed rate of $30 \mathrm{~m} \cdot \mathrm{min}^{-1}$.

Key words: surface roughness, planing, sanding, processing conditions, feed rate
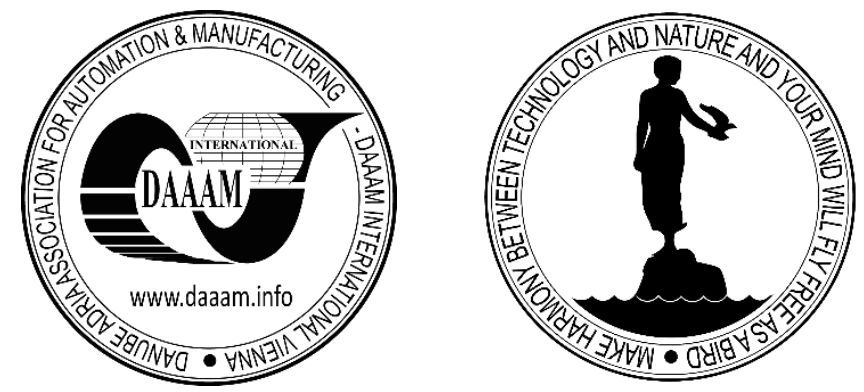

Authors' data: Smajic, Selver ${ }^{1}$; Jovanovic, Juraj ${ }^{1}$; Beljo Lucic, Ruzica ${ }^{1 ; 1}$ Department of process engineering, Faculty of forestry, University of Zagreb, Zagreb, Croatia, *Corresponding author: jjovanov@sumfak.hr

This Publication has to be referred as: Smajic, S[elver]; Jovanovic, J[uraj] \& Beljo Lucic, R[uzica] (2020). Effect of Different Processing on the Roughness of Oak and Beech Wood, Chapter 18 in DAAAM International Scientific Book 2020, pp.217-226, B. Katalinic (Ed.), Published by DAAAM International, ISBN 978-3-902734-27-3, ISSN 1726-9687, Vienna, Austria

DOI: $10.2507 /$ daaam.scibook.2020.18 
Smajic, S.; Jovanovic, J. \& Beljo Lucic, R.: Effect of Different Processing on the R...

\section{Introduction}

A very important place in all technological treatments is reserved for surface quality. Quality of the surface directly affects the quality and strength of wood joints in the further production flow. Geometric irregularities are deviations from ideal overall geometric shape and surface roughness [1] (Aydin, I., 2003).

According to [2] (Dornyak, OR, 2003) surface geometry is always defined on the basis of irregularities resulting from macroscopic, microscopic, and submicroscopic characteristics. Researcher [3] (Temiz et.al. 2005) showed that surface roughness depends on the inherent morphological structures of wood and method of processing.

Quality of the treated wood surface depends on the anatomical structure of wood species and wood processing parameters, such as cutting depth, feed speed, tool rotational frequency, feed rate and the cutting angle [5] (Obucina et al.). It is assumed that the surface roughness of the machined surface of hardwood increases with the increasing radius of the wedge [4] (Keturakis, G., 2007). In one research [6] (Aslan S. 2008 ,) it was shown that the grain size during sanding affects surface roughness. With increasing feed rate, surface roughness increases [7] (Škaljić, N., 2010). Factors that significantly affect surface roughness according to [8] (Laina, R., 2017) are technological process of wood machining and wood species.

In this paper, we have measured the surface roughness of the oak and beech wood samples and the influence of different processing parameters.

\section{Materials and methods}

Measurements were carried out on samples of oak and beech wood. Basic dimensions of samples before peripheral milling were: $40 \times 40 \times 600 \mathrm{~mm}$. Beech (Fagus sylvatica L.) and oak (Quercus robur L.) samples had average moisture content of 8\%. Figure 1 shows the samples prepared for testing. Samples were made with radial texture from the pith area. Before milling they were conditioned at $20{ }^{\circ} \mathrm{C}$ in relative air humidity 65 $\pm 5 \%$. The measurements were carried out on samples machined with two different methods of wood processing.

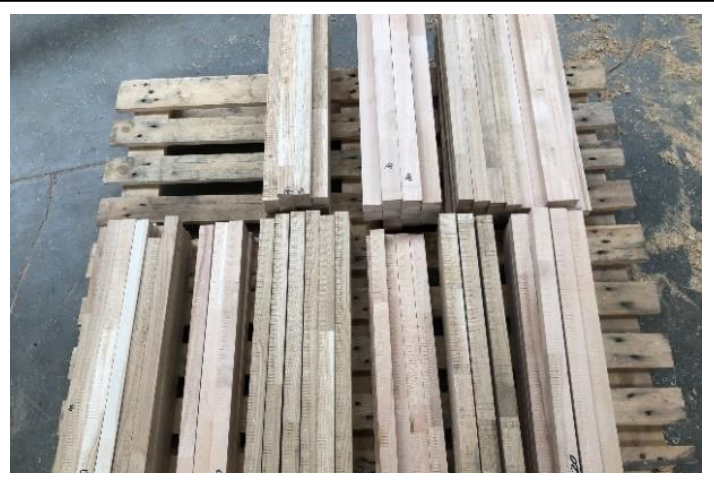

Fig. 1. Samples for experimental research. 


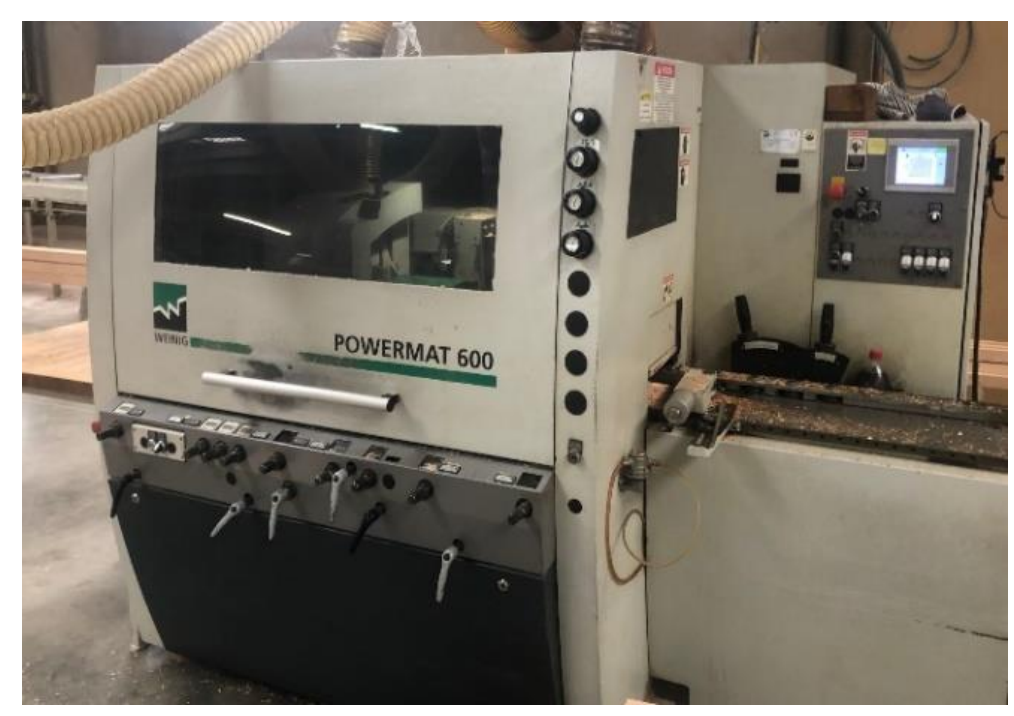

Fig. 2. Four side planer machine.

The first samples were machined by peripheral milling in radial direction. Milling is one of the most common methods of wood processing [9] (Kvietkova, et. Al. 2015). The quality of the machined surface was measured on a group of samples that were machined by peripheral milling on Weinig Powermat 600 machine (figure 2). The planning tool had four blades and feed rate was 10, 15, 20, 25, and $30 \mathrm{~m} \cdot \mathrm{min}^{-1}$ (figure $3)$. Feed speed also has an important influence on the roughness of the machined surface, [10] (Carrano 2002), [11] (De Moura and Hernandez 2006). The cutting depth was $1.00 \mathrm{~mm}$ and the blade rake angle was $\gamma=15^{\circ}$. The tool diameter was $\Phi=125 \mathrm{~mm}$ and rotational frequency was $8000 \mathrm{~min}^{-1}$.

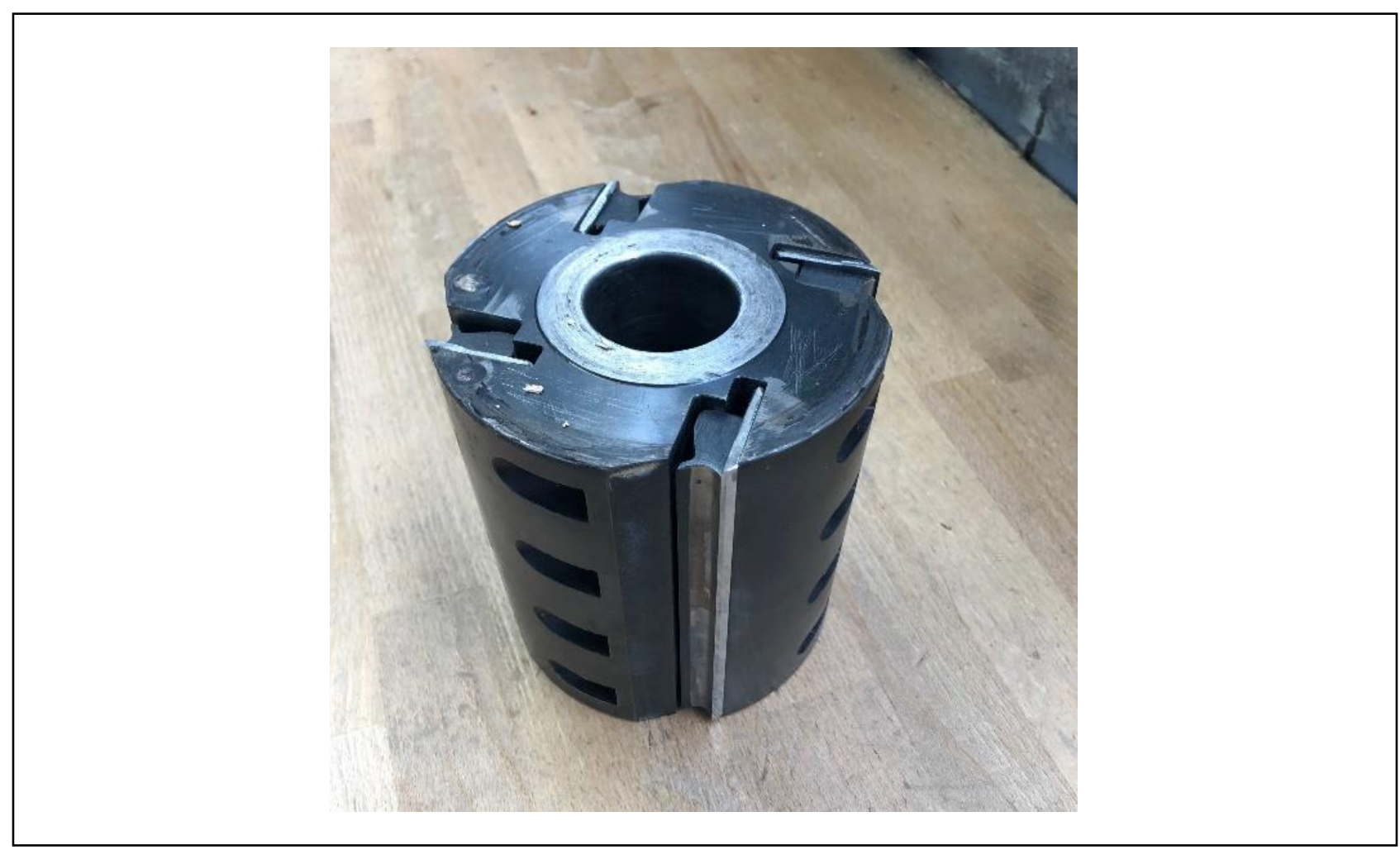

Fig. 3. Milling head with 4 blades 


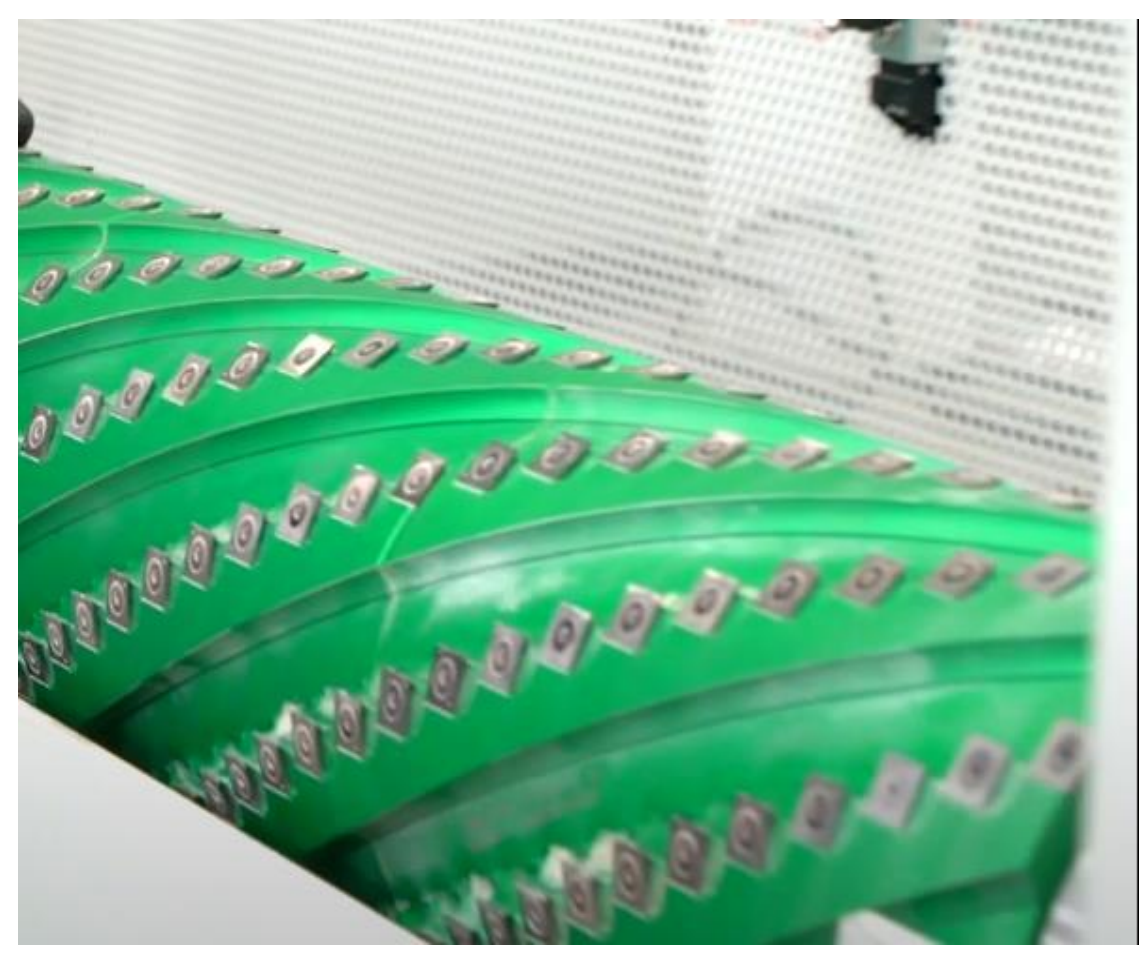

Fig. 4. Milling head with 180 inserts

Another group of samples was machined on a combined machine with aggregators for planing and sanding (Viet Opera). The diameter of the milling unit was $250 \mathrm{~mm}$, with four spirally twisted rows of cutting tools. In one row there were 180 cutting inserts dimensions $14 \times 14 \times 2 \mathrm{~mm}$. The rake angle of blades was $\gamma=15^{\circ}$ and feed rate $10 \mathrm{~m} \cdot \mathrm{min}^{-}$ 1 .

Grain size takes an important role in the sanding process and directly affects surface roughness (Gurau, 2005). The depth of milling and sanding was $1.5 \mathrm{~mm}$. After milling unit, in the same pass, samples were sanded with P80 granulation, at a pressure of 6 $\mathrm{kg} / \mathrm{cm}^{2}$. The thickness of the planing and sanding was $1.5 \mathrm{~mm}$. According to [13] (De Moura and Hernandez 2005), surface roughness is considered as the main parameter for assessing surface quality after planing or sanding.

After machining the samples, surface roughness was measured using an electromechanical profilometer Mitutoyo SJ-500. The device consists of a central measuring console with a vertically placed test needle, with a radius of $10 \mu \mathrm{m}$. The test needle moved at a constant speed of $1 \mathrm{~mm} / \mathrm{s}$, converting a vertical displacement of $40 \mathrm{~mm}$ into an electrical signal. The measuring standard were ISO 4287:1997 with total 5 sampling lengths. Cut-off value was set up for $8 \mathrm{~mm}$.

Each researched wood species has specific anatomical properties, beech has diffusion pores while oak has ring pores. We needed to exclude anatomical structure in measuring roughness parameters. Both specimens are measured in the radial section, pith area. On beech, stylus traverse on the whole annual ring, while on oak we 
measured only late area of annual growth. Table 1 shows the setup of the surface quality measuring device Mitutoyo SJ-500.

\begin{tabular}{|l|l|}
\hline Cut-off value & $8 \mathrm{~mm}$ \\
\hline Number of sampling lenghts & 5 \\
\hline Traverse speed & $1,00 \mathrm{~mm} / \mathrm{s}$ \\
\hline Stylus tip radius & $10,00 \mu \mathrm{m}$ \\
\hline Stylus tip angle & $90^{\circ}$ \\
\hline
\end{tabular}

Tab. 1. Setup of measuring device for roughness testing (Mitutoyo SJ-500).

After measurement, the surface roughness results are presented graphically. The measurement was performed with a total of five measurements of the measuring stylus on one sample, for each feed rate. The parameters $\mathrm{Ra}, \mathrm{Rz}$, and $\mathrm{Rq}$ were measured, according to the ISO 4287:1997 standard. This method can be used to compare and assess the difference in surface roughness created by planing and sanding [14] (Kilic, M., et. Al. 2006).

\section{Results and discussion}

Table 2 shows the values of the measured surface roughness on samples of oak wood. Both species were planed on Weinig Powermat 600, and samples machined on an automatic machine with aggregates for milling and sanding. The values of standard deviation and standard error are also given in the same table.

\begin{tabular}{|c|c|c|c|c|c|c|c|c|c|c|c|}
\hline \multicolumn{12}{|c|}{$\begin{array}{l}\text { Descriptive Statistics of surface roughness, } \mathrm{Ra}, \mathrm{Rq}, \mathrm{Rz} \text { and standard deviation of beech and oak } \\
\text { samples }\end{array}$} \\
\hline Species & $\begin{array}{c}\text { Feed } \\
\text { speed } \\
{[\mathrm{m} / \mathrm{min}} \\
]\end{array}$ & $\mathrm{N}$ & $\begin{array}{c}\mathrm{Ra} \\
{[\mu \mathrm{m}]} \\
\mathrm{Mea} \\
\mathrm{n} \\
\end{array}$ & $\begin{array}{c}\mathrm{Ra} \\
{[\mu \mathrm{m}]} \\
\text { Std. } \\
\text { Dev. }\end{array}$ & $\begin{array}{c}\mathrm{Ra} \\
{[\mu \mathrm{m}]} \\
\text { Std. } \\
\text { Err. }\end{array}$ & $\begin{array}{c}\mathrm{Rq} \\
{[\mu \mathrm{m}]} \\
\mathrm{Mea} \\
\mathrm{n}\end{array}$ & $\begin{array}{c}\mathrm{Rq} \\
{[\mu \mathrm{m}]} \\
\text { Std. } \\
\text { Dev. }\end{array}$ & $\begin{array}{l}\mathrm{Rq} \\
{[\mu \mathrm{m}]} \\
\text { Std. } \\
\text { Err. }\end{array}$ & $\begin{array}{c}\mathrm{Rz} \\
{[\mu \mathrm{m}]} \\
\mathrm{Mea} \\
\mathrm{n}\end{array}$ & $\begin{array}{c}\mathrm{Rz} \\
{[\mu \mathrm{m}]} \\
\text { Std. } \\
\text { Dev. }\end{array}$ & $\begin{array}{c}\mathrm{Rz} \\
{[\mu \mathrm{m}]} \\
\text { Std. } \\
\text { Err. }\end{array}$ \\
\hline & & 360 & 6.99 & 2.38 & 0.13 & 8.84 & 2.97 & 0.16 & 46.31 & $\begin{array}{c}15.6 \\
2\end{array}$ & 0.82 \\
\hline $\begin{array}{l}\text { Total } \\
\text { Beech }\end{array}$ & & 180 & 7.59 & 2.32 & 0.17 & 9.72 & 2.89 & 0.22 & 51.00 & $\begin{array}{c}15.9 \\
0\end{array}$ & 1.18 \\
\hline Total Oak & & 180 & 6.38 & 2.28 & 0.17 & 7.97 & 2.79 & 0.21 & 41.63 & $\begin{array}{c}13.8 \\
7\end{array}$ & 1.03 \\
\hline \multirow{6}{*}{$\begin{array}{c}\text { Feed } \\
\text { speed } \\
{[\mathrm{m} / \mathrm{min}]}\end{array}$} & 10 & 60 & 3.84 & 1.05 & 0.14 & 4.99 & 1.36 & 0.17 & 26.36 & 6.45 & 0.83 \\
\hline & 15 & 60 & 5.08 & 1.07 & 0.14 & 6.59 & 1.48 & 0.19 & 36.71 & 8.69 & 1.12 \\
\hline & 20 & 60 & 6.93 & 1.27 & 0.16 & 8.78 & 1.61 & 0.21 & 44.97 & 8.24 & 1.06 \\
\hline & 25 & 60 & 8.32 & 1.44 & 0.19 & 10.40 & 1.92 & 0.25 & 55.06 & $\begin{array}{c}12.1 \\
3\end{array}$ & 1.57 \\
\hline & 30 & 60 & 9.32 & 1.18 & 0.15 & 11.60 & 1.57 & 0.20 & 58.65 & 9.22 & 1.19 \\
\hline & Sanded & 60 & 8.43 & 1.94 & 0.25 & 10.71 & 2.63 & 0.34 & 56.14 & $\begin{array}{c}15.3 \\
6\end{array}$ & 1.98 \\
\hline \multirow{3}{*}{ Beech } & 10 & 30 & 4.49 & 0.99 & 0.18 & 5.80 & 1.28 & 0.23 & 29.57 & 6.49 & 1.18 \\
\hline & 15 & 30 & 5.62 & 1.12 & 0.20 & 7.36 & 1.45 & 0.27 & 38.77 & 8.16 & 1.49 \\
\hline & 20 & 30 & 7.14 & 1.42 & 0.26 & 9.16 & 1.72 & 0.31 & 45.04 & 7.73 & 1.41 \\
\hline
\end{tabular}


Smajic, S.; Jovanovic, J. \& Beljo Lucic, R.: Effect of Different Processing on the R...

\begin{tabular}{|c|c|c|c|c|c|c|c|c|c|c|c|}
\multirow{6}{*}{} & 25 & 30 & 9.13 & 1.29 & 0.23 & 11.55 & 1.63 & 0.30 & 63.31 & 8.81 & 1.61 \\
\cline { 2 - 12 } & 30 & 30 & 9.80 & 0.85 & 0.16 & 12.35 & 1.12 & 0.20 & 63.31 & 6.14 & 1.12 \\
\cline { 2 - 12 } & Sanded & 30 & 9.36 & 1.32 & 0.24 & 12.09 & 1.58 & 0.29 & 65.97 & 8.01 & 1.46 \\
\hline \multirow{6}{*}{ Oak } & 10 & 30 & 3.19 & 0.62 & 0.11 & 4.17 & 0.84 & 0.15 & 23.15 & 4.60 & 0.84 \\
\cline { 2 - 11 } & 15 & 30 & 4.54 & 0.70 & 0.13 & 5.82 & 1.07 & 0.20 & 34.65 & 8.85 & 1.61 \\
\cline { 2 - 11 } & 20 & 30 & 6.71 & 1.09 & 0.20 & 8.40 & 1.43 & 0.26 & 44.89 & 8.86 & 1.62 \\
\cline { 2 - 10 } & 25 & 30 & 7.51 & 1.09 & 0.20 & 9.25 & 1.44 & 0.26 & 46.81 & 8.98 & 1.64 \\
\cline { 2 - 10 } & 30 & 30 & 8.85 & 1.29 & 0.23 & 10.84 & 1.61 & 0.29 & 53.98 & 9.51 & 1.74 \\
\cline { 2 - 9 } & Sanded & 30 & 7.49 & 2.02 & 0.37 & 9.33 & 2.76 & 0.50 & 46.31 & 14.6 & 2.68 \\
\hline
\end{tabular}

Tab. 2. Measured values of surface roughness (Ra, Rq, Rz), standard deviation and error of beech and oak samples.

The Analysis of Variance for tested samples is presented in table 3.

\begin{tabular}{|c|c|c|c|c|c|c|c|c|c|c|c|}
\hline \multicolumn{12}{|c|}{ Analysis of Variance, Marked effects are significant at $p<0,05000$} \\
\hline $\begin{array}{c}\text { Variabl } \\
\mathrm{e}\end{array}$ & $\begin{array}{l}\text { Multipl } \\
\text { e R1 }\end{array}$ & $\begin{array}{c}\text { Multipl } \\
\text { e R2 }\end{array}$ & $\begin{array}{c}\text { Adjuste } \\
\text { d R2 }\end{array}$ & $\begin{array}{c}\text { SS } \\
\text { Effect }\end{array}$ & $\begin{array}{c}\mathrm{dS} \\
\text { Effec } \\
\mathrm{t}\end{array}$ & $\begin{array}{c}\text { MS } \\
\text { Effect }\end{array}$ & $\begin{array}{l}\text { SS } \\
\text { Error }\end{array}$ & $\begin{array}{c}\mathrm{dF} \\
\text { Erro } \\
\mathrm{r}\end{array}$ & $\begin{array}{l}\text { MS } \\
\text { Error }\end{array}$ & $\mathrm{F}$ & $\mathrm{P}$ \\
\hline $\begin{array}{c}\mathrm{Ra} \\
{[\mu \mathrm{m}]}\end{array}$ & $\begin{array}{r}0,86706 \\
6\end{array}$ & $\begin{array}{r}0,75180 \\
4\end{array}$ & $\begin{array}{r}0,74395 \\
9\end{array}$ & 1523,11 & 11 & 138,465 & 502,83 & 348 & 1,44492 & $\begin{array}{r}95,8288 \\
0\end{array}$ & $\begin{array}{r}0,0 \\
0\end{array}$ \\
\hline $\begin{array}{c}\mathrm{Rq} \\
{[\mu \mathrm{m}]}\end{array}$ & $\begin{array}{r}0,85538 \\
4\end{array}$ & $\begin{array}{r}0,73168 \\
2\end{array}$ & $\begin{array}{r}0,72320 \\
1\end{array}$ & 2317,04 & 11 & 210,640 & 849,69 & 348 & 2,44164 & $\begin{array}{r}86,2698 \\
7\end{array}$ & $\begin{array}{r}0,0 \\
0\end{array}$ \\
\hline $\begin{array}{c}\mathrm{Rz} \\
{[\mu \mathrm{m}]}\end{array}$ & $\begin{array}{r}0,83529 \\
9 \\
\end{array}$ & $\begin{array}{r}0,69772 \\
4 \\
\end{array}$ & $\begin{array}{r}0,68816 \\
9\end{array}$ & $\begin{array}{r}61103,9 \\
2\end{array}$ & 11 & $\begin{array}{r}5554,90 \\
2\end{array}$ & $\begin{array}{r}26472,1 \\
8\end{array}$ & 348 & $\begin{array}{r}76,0694 \\
8\end{array}$ & $\begin{array}{r}73,0240 \\
5 \\
\end{array}$ & $\begin{array}{r}0,0 \\
0 \\
\end{array}$ \\
\hline
\end{tabular}

Tab. 3. Analysis of Variance of beech and oak surface roughness measured values $\mathrm{Ra}, \mathrm{Rq}, \mathrm{Rz}$

Table 4. shows results of Multivariate Tests of Significance. Every marked difference is significant at $\mathrm{p}<0.05$.

\begin{tabular}{|l|l|l|r|r|l|l|}
\hline \multicolumn{7}{|c|}{$\begin{array}{l}\text { Multivariate Tests of Significance (Beech and Oak) } \\
\text { Sigma-restricted parameterization } \\
\text { Effective hypothesis decomposition }\end{array}$} \\
\hline Effect & Test & Value & \multicolumn{1}{l|}{ F } & Effect df. & Error df. & \multicolumn{1}{l|}{ p } \\
\hline Intercept & Wilks & 0,024835 & 4528,728 & 3 & 346,0000 & 0,0000000 \\
\hline Species & Wilks & 0,728318 & 43,022 & 3 & 346,0000 & 0,0000000 \\
\hline Feed speed [m/min] & Wilks & 0,208203 & 48,767 & 15 & 955,5550 & 0,0000000 \\
\hline $\begin{array}{l}\text { Species*Feed speed } \\
\text { [m/min] }\end{array}$ & Wilks & 0,707402 & 8,510 & 15 & 955,5550 & 0,0000000 \\
\hline
\end{tabular}

Tab. 4. Multivariate Tests of Significance results of beech and oak samples

Figure 5, 6, and 7 show diagrams with summary results of measured roughness parameters $\mathrm{Ra}, \mathrm{Rq}$, and $\mathrm{Rz}$ of beech and oak samples processed at different feed speeds, and machined on an automatic machine with aggregate for planing and sanding (Viet opera). 


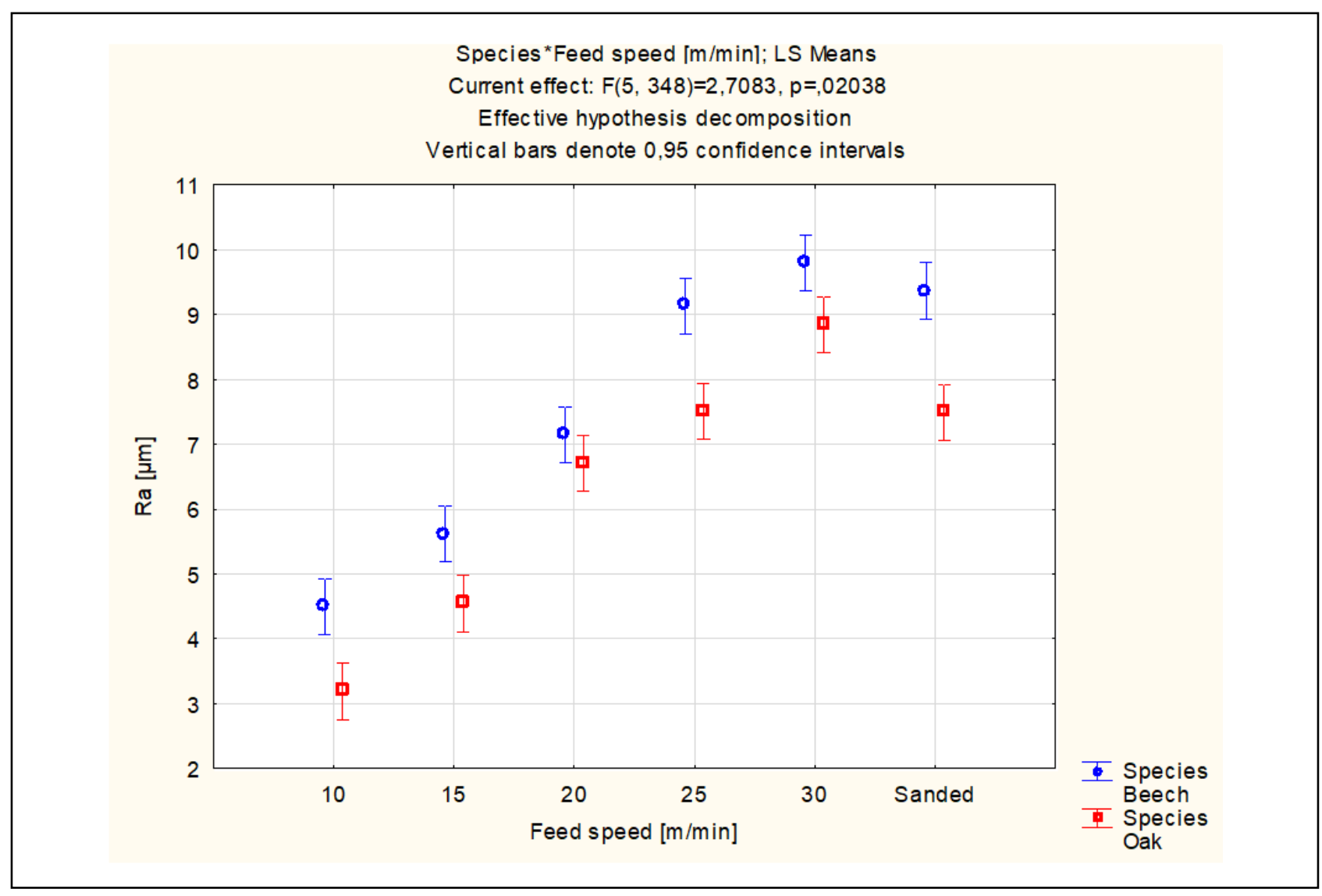

Fig. 5. Statistical values of surface roughness parameter Ra of beech and oak samples.

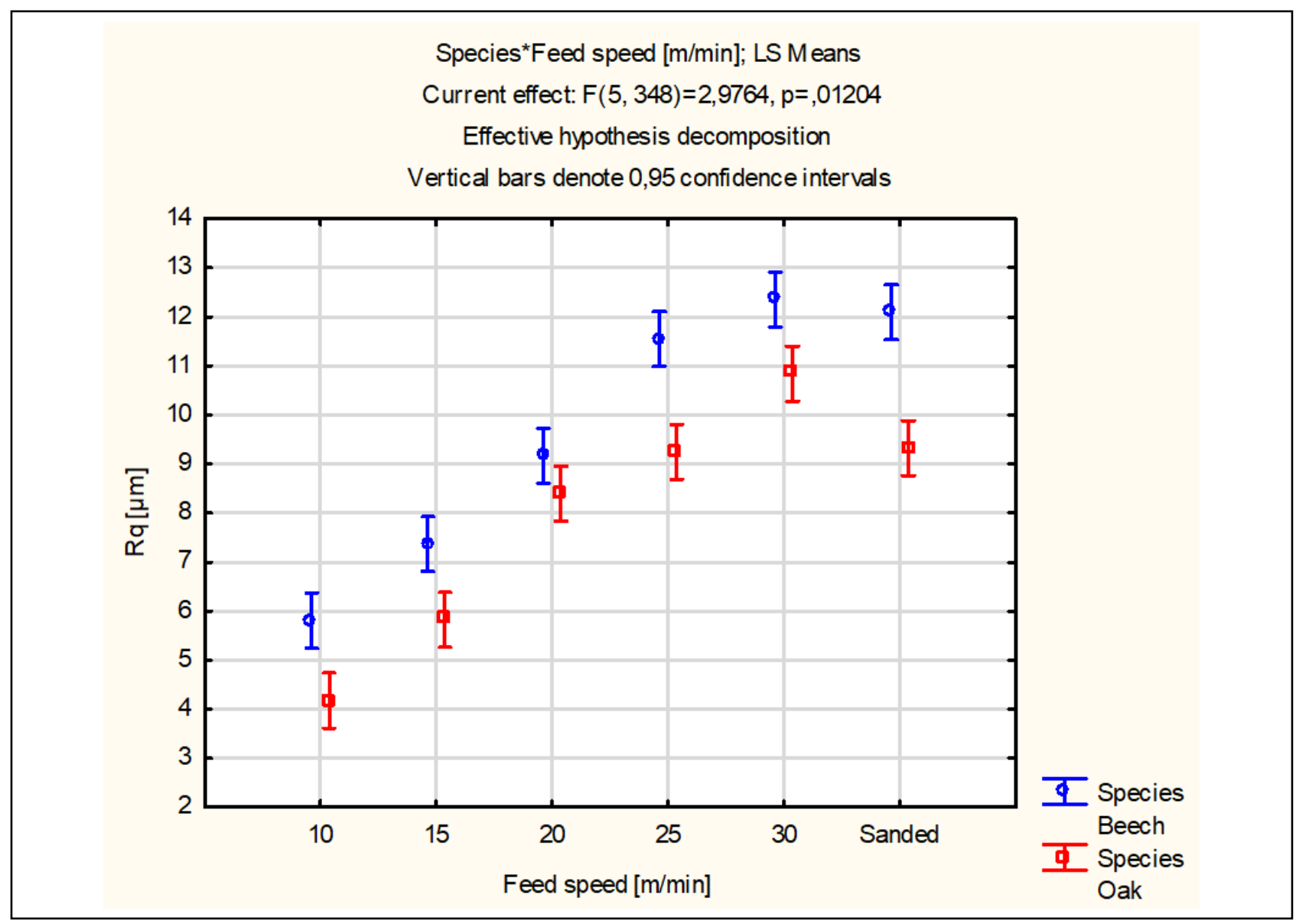

Fig. 6. Statistical values of surface roughness $\mathrm{Rq}$ of beech and oak samples. 
Smajic, S.; Jovanovic, J. \& Beljo Lucic, R.: Effect of Different Processing on the R...

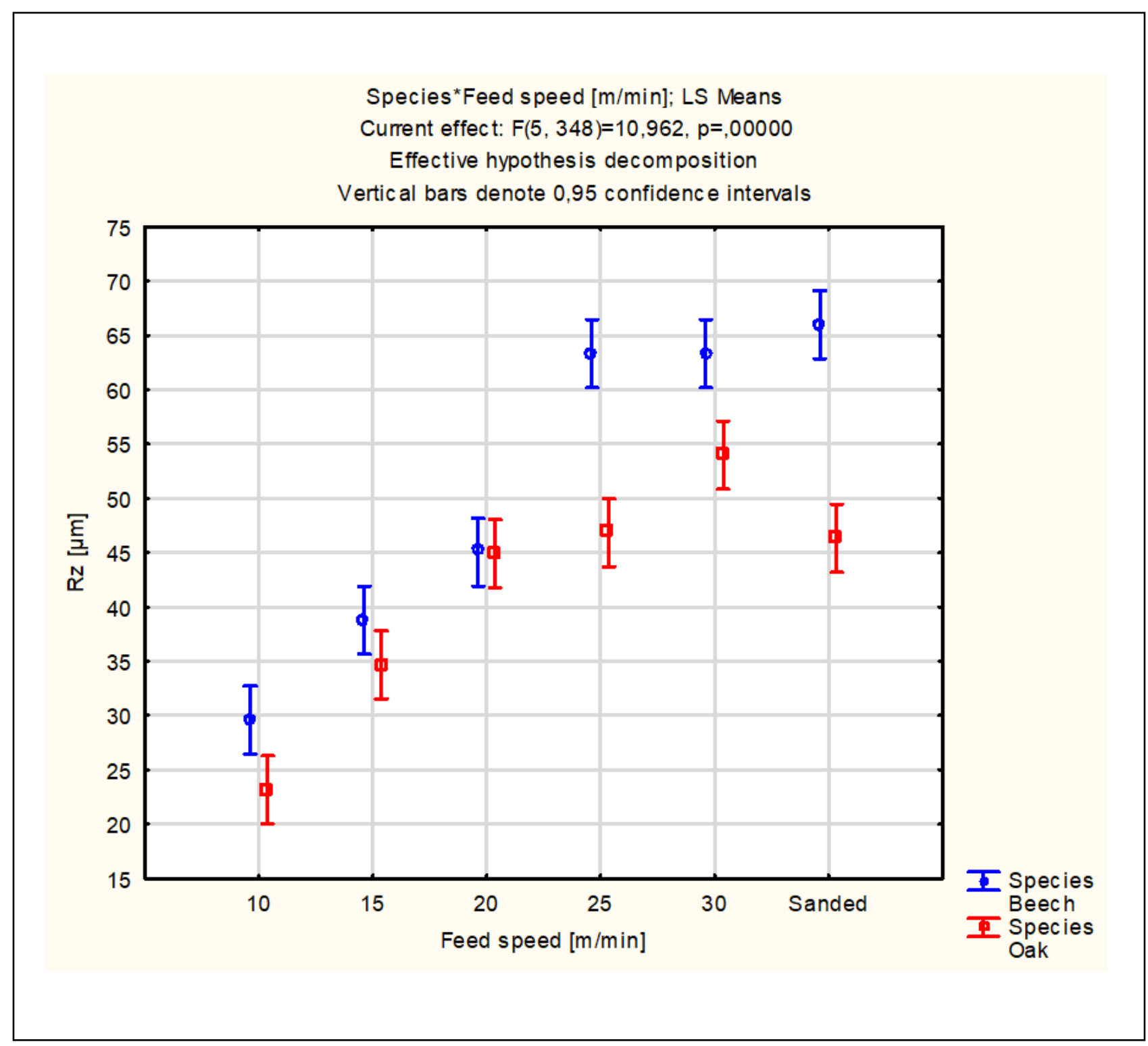

Fig. 7. Statistical values of surface roughness Rz of beech and oak samples.

\section{Conclusion}

It can be seen that all observed parameters of surface roughness increase with increasing feed speed.

If we look at the surface roughness in relation to the change of the feed speed during planning, then we see that beech samples planned at all feed speeds have higher roughness than oak samples planed with same parameters.

The lowest value of surface roughness was at beech and oak samples planed at feed speed of $10 \mathrm{~m} \cdot \mathrm{min}-1$, and the highest roughness had samples of beech and oak wood planed at feed speeds of $30 \mathrm{~m} \cdot \mathrm{min}-1$. 
This can be considered as an expected research result. On automatic milling and sanding machine (which was the second machining method), the measured overall roughness through parameters $\mathrm{Ra}, \mathrm{Rq}, \mathrm{Rz}$ of beech samples was higher than of oak samples, which can be seen from diagrams shown earlier.

Study results showed different average values of surface roughness parameters for different machining methods for both wood species. The finer surface finish had oak wood in all machining conditions. Similar roughness parameters $\mathrm{Ra}, \mathrm{Rq}, \mathrm{Rz}$ on beech and oak wood samples can be seen at peripheral milling with feed rate of $20 \mathrm{~m} \cdot \mathrm{min}-1$.

Also, from the standing of productivity we could achieve higher production rate with peripheral milling than with sanding of wood elements with the same surface quality or better.

In analysing variances, we see that there is a significant difference between the roughness of measured samples. Also, there can be seen significant differences between individual groups.

Considered on presented results, research will be continued in the future, with involving new wood species, new parameters of machine processing control, and with increasing a number of samples.

\section{References}

Aydin I., Colakoglu G. (2003). Roughness on wood surfaces and roughness measurement methods, Research gate publication

Dornyak O.R. (2003). Modelling of the Rheological Behaviour of Wood in Compression Processes, Journal of Engineering Physics and Thermophysics, 76, 648654

Temiz, A., Yildiz, U.C., Aydin, I., Eikenes, M., Alfredsen, G. and Colakoglu, G. (2005). Surface roughness and colour characteristic of wood treated with preservatives after accelerated weathering test, Applied Surface Science 250 (1-4), 35-42.

Keturakis, G.; Juodeikiene, I. (2007). Investigation Of Milled Wood Surface Roughness, Materials Science (Medžiagotyra), 13 (1).

Obućina, M.; Smajić, S.; Škaljić, N. \& Beljo Lučić, R. (2010). Effect of Rotation Speed and Wood Species on Roughness of Machined Surface, Proceedings of the 21st International DAAAM Symposium, Zadar, ISSN 1726-9679, ISBN 978-3- 901509-735, Katalinic, B. (Ed.), pp.449-450, Published by DAAAM International, Vienna, Austria

Aslan S., Coşkun H., Kiliç M. (2008). The effect of the cutting direction, number of blades and grain size of the abrasives on surface roughness of Taurus cedar (Cedrus Libani A. Rich.) woods, Building and Environment, 43, 696-701

Škaljić N.; Beljo Lučić R.; Čavlović A.; Obućina M. (2010). Effect of Feed Speed and Wood Species on Roughness of Machined Surface, Drvna Industrija Vol_60_4, 2010. 
Smajic, S.; Jovanovic, J. \& Beljo Lucic, R.: Effect of Different Processing on the R...

Laina R.; Sanz-Lobera A.; Villasante A.; Lopez-Espi P.; Martinez-Rojas J.; Alpuente J.; Sanches-Montero R.; Vignote S. (2017). Effect of the anatomical structure of wood on surface roughness, Maderas 19_2: 203-212,

Kvietkova, M., Gašparnik, M., Gaff, M. (2015). Milled Beech Roughness, BioResources 10(3), 4226-4238.

Carrano, A.L.J.B., Taylor, R., Lemaster, R. (2002). Parametric characterization of peripheral sanding, Forest Products Journal, 52(9):44-50.

De Moura, L.F., Hernandez, R.E. (2006). Effects of abrasive mineral, grit size and feed speed on the quality of sanded surfaces of sugar maple wood, Wood Science and Technology, 40(6):517-530.

Gurau, L., William, M., Irle, M. (2005). Processing roughness of sanded wood surfaces, Holz als Roh und Werkstoff, 63(1):43-52

De Moura, L.F., Hernandez, R.E. (2005). Evaluation of varnish coating performance for two surfacing methods on sugar maple wood, Wood and Fiber Science, 37(2):355366.

Kilic, M., Hirizoglu, S., Burdurlu, E. (2006). Effect of machining on surface roughness of wood, Science direct, Building and Environment 41 (1074-1078) 